\title{
DE LABADISTEN IN SURINAME
}

\author{
DOOR
}

PROF. DR. L. KNAPPERT

(Met een kaart)

Zoo overvloedig als het materiaal is, waaruit wij de geschiedenis der huisgemeente in ons land kunnen opbouwen, zoo poover zijn de berichten over hare lotgevallen in Suriname. Noch in de archieven der Kolonie uit het tijdperk sinds 24 November 1683 (de ambtsaanvaarding van gouverneur Cornelis Aerssens van Sommelsdijk) noch in het archief van de Geoctrooyeerde Sociëteit van Suriname, in dat jaar opgericht, vindt men gegevens over hun verblijf en ondergang. Ook de gedrukte werken stellen te leur, zoowel de geschriften der labadisten zelven als die hunner bestrijders uit dien tijd. Dat doen ook de latere auteurs. Heppe wijdt aan de kolonisatie ééne bladzijde, Goeters geeft de geschiedenis der broeders slechts tot hun vertrek uit Amsterdam naar Herford. In de werken over Suriname is de oogst al even klein. De eerste schrijver, die in aanmerking komt, is J. D. Herlein, „Beschrijvinge van de volkplantinge Zuriname”, Leeuwarden, 1718. Hij schreef dus een jaar vóór (gelijk wij zien zullen) de plantage der kolonisten in andere handen overging. Hij noemt haar eigendom van de zusters der heeren van Sommelsdijk en geeft als zijne meening te kennen, dat enkele labadisten er heen getrokken waren met het oogmerk daar een beter leven te leiden tot bevordering der zaligheid en liefde met malkanderen in gemeenschap van goederen. „Maar alzoo” besluit hij filosofisch, ,in zulke gevallen de zinnelijkheid der menschen niet met malkanderen overeenkomt, zo 
heeft dit ook geen stand gehouden" ${ }^{1}$. Th. Pistorius in 1763, Ph. Fermin in 1769, J. J. Hartsinck in 1770, J. G. Stedman in 1799 geven ons rechtstreeks weinig of niets, wel veel natuurlijk dat ter toelichting dienen kan. De lateren en algemeen bekenden, C. A. van Sypesteyn, J. Wolbers b.v. blijken allen te steunen op het werk van $H$. van Berkum, „De Labadie en de labadisten”, Sneek, 1851, die II 132-153, slap-novellistisch, van de kolonisatie in Suriname en Nieuw-Nederland vertelt. Hij ontleent zijn verhaal aan W. à Brakel, „Leer en leyding der labadisten ontdekt” en "Redelijke godsdienst”, doch vooral aan Petrus Dittelbach, „Verval en val der labadisten”, 1692 en in datzelfde jaar een tweede druk. Het pamflet is vrij zeldzaam geworden; ik gebruik een exemplaar uit de Koninklijke Bibliotheek. Van Berkum dan vertelt het in hoofdzaken na, maar laat ook veel weg, en het is de moeite waard het oorspronkelijke nog eens te laten spreken. $\mathrm{Er}$ is één bezwaar. Dittelbach, predikant te Nendorp in OostFriesland, waar hij een heftigen twist had met den schoolmeester Menke Gerritsz., werd door invloed der huisgemeente in 1676 te Wieuwerd beroepen, maar bedankte, al was hij een ijverig labadist. Ambteloos daarna te Amsterdam levende, vertaalde hij o. a. Anna Maria van Schurman's „Eukleria” uit het Latijn in het Hollandsch, maar liet zich ten slotte toch met vrouw en kinderen in de huisgemeente op Waltha-state opnemen. Het duurde niet lang, of de rigoristische methode volgens welke de labadisten hunne kinderen opvoedden en hunne huwelijkstheorieën maakten hem afkeerig en hij verliet Wieuwerd als een afvallige. Doch anders dan b.v. in een gelijksoortig geval Obbe Philipsz, die zich van de melchiorieten afwendde, maar zacht en verschoonend van hen bleef spreken, haatte Dittelbach wat hij eens had liefgehad, en vandaar dat men zijne betrouwbaarheid pleegt in twijfel te trekken en te zeggen dat hij met voorzichtigheid moet gebruikt worden ${ }^{2}$ ). Een bezwaar inderdaad. Maar dit geldt minder de feiten dan de verklaring ervan. Wat hij vertelt

1) Herlein, a. w. blz. 89 .

2) B. v. W. P. C. Knuttel in Nieuw Ned. Biogr. Wrdbk. III, 289. 
van der labadisten daden en lotgevallen is betrouwbaar genoeg, slechts stelt hij ze gaarne in ongunstig licht. Wij volgen dus eerst zijn verhaal.

Reeds De Labadie ${ }^{\mathbf{1}}$ ) had er aan gedacht het werk des Heeren uit te breiden en een vaag plan voor Madagascar gemaakt. Inderdaad schijnt mij dit de eigenlijke oorzaak der labadistische kolonisatiepogingen. Zich aanhang verwerven ook in vreemde landen, dat was het doel, waarbij nog kwam, dat de gemeente op Waltha-state sterk groeide en gebrek aan ruimte kreeg. Ik ben het derhalve met Heppe eens, dat zij aan zending niet gedacht hebben, daartoe ook niet bekwaam waren, dat zij niet de overwinning der wereld door het Christendom bedoelden, maar de vergadering van wie zich van de wereld afzonderden ${ }^{2}$ ). Het is waar, dat de zendingsgedachte niet geheel ontbrak. Juffrouw Huygens, die 30 Januari 1680 te Wieuwerd overleed, zeide op haar sterfbed, dat zij nu heenging om in aller naam Jezus te omhelzen, dat zij den Heer Jezus zou bidden voor de bekeering der arme Indianen, voor wie zij eene zeer teedere en bijzondere genegenheid koesterde, wel willende dat zij nog tot hen gaan kon, hoe zwak, ziek en oud zij ook zijn mocht ${ }^{3}$ ). Doch deze uitspraak staat toch wel alleen.

Hoe men er toe kwam naar Suriname te gaan is bekend. Cornelis Aerssens van Sommelsdijk (Dittelbach noemt hem voortdurend van Somerdijk!) was 21 Mei 1683 voor $\frac{1}{3}$ eigenaar der kolonie Suriname geworden, het tweede derdepart verkocht de nieuwe W. I. Compagnie aan Amsterdam, het derde behield zij voorloopig zelve. Te zamen noemden zij zich de „Geoctroyeerde Societeit van Suriname" onder het oppergezag der Staten-Generaal. Cornelis werd tevens gouverneur en, toen hij naar zijn post vertrok, gingen talrijke Fransche uitgewekenen met hem.

1) Voor hem mag ik wel verwijzen naar mijn artikel in $N . N$. B.W. II 743 en Gesch. Ned. Herv. Kerk I, 278-287.

2) H. Heppe, Geschichte des Pietismus und der Mystik in der Reform. Kirche namentlich der Niederlande, 1879, S. 371, noot.

$\left.{ }^{3}\right)$ Yvon, Fìdelle Narré des états des dernières paroles et dispositions etc. 1683, pag. 101. Er is eene Nederl. vertaling. Nog Heppe a. w., S. 353, noot zocht het tevergeefs. Ik gebruikte een exemplaar van de Thysiana. 
Hij had, sinds de dagen, dat zijn grootvader François gezant bij koning Hendrik IV geweest was, betrekkingen in Frankrijk en was ook met eene française getrouwd, Marguérite du Puy de St. André Montbrun, die hem echter niet vergezelde ${ }^{\mathbf{1}}$ ). Voor de labadisten was dit een kans, Fransch reisgezelschap lokte hen aan, van den nieuwen gouverneur konden zij allen steun verwachten. Zijne drie zusters Anna, Maria en Lucia waren ijverige leden der huisgemeente, aan wie zij immers ook haar slot Waltha - haar moeder Lucia van Waltha had het bij haar huwelijk, 27 Januari 1630, haren gemaal Cornelis van Aerssen, zoon van François, aangebracht - ter vestiging hadden afgestaan en waar zij sinds met de anderen, onder leiding van Yvon, in gemeenschap van goederen leefden. Zoo lag het dan voor de hand, dat eenigen hunner in den zomer van 1683 medegingen om het land te bezien, onder wie ook broeder Pierre Bont. Doch zij kwamen niet - als de verspieders uit Kanaän - met berichten terug van een land dat overvloeide van melk en van honing en met een druiventros, aan een stok tusschen twee mannen in gedragen ${ }^{2}$ ). Het oordeel der meesten luidde ongunstig.Doch (en hier keer ik tot Dittelbach terug) ${ }^{3}$ ) de Heer deed hen evenwel gevoelen, dat dit een Soar zou worden voor Zijne kerk, wanneer Hij door Zijne oordeelen de tegenwoordige wereld met hare valsche pieusen zou te niet maken ${ }^{4}$ ). Yvon en de andere leiders hadden al uitgekipt wie gaan zouden, hun moest men dan van tijd tot tijd vragen, wat zij dienaangaande van den Heer gewaar werden, om hen aldus te doen gevoelen dat de goddelijke leiding hier meer het bestier had dan die van vader Yvon. Men zeide hun wat een gezegend land het daarginds was en vooral, dat zij daar grooter vrijheid genieten zouden, dan hier te midden

1) Over de Aerssens de artikelen in N.N.B.W, III, 8-14. Bij de literatuur over François (1) thans ook Un envoyé hollandais à la cour de Henri IV. Lettres inédites de François d'Aerssen à Jacques Valcke, tresorier de Zélande, I599-I603, ed. dr. J. Nouaillac, Paris, Champion, 1925.

2) Numeri 13, 23, 27.

3) Dittelbach, $a . w$. blz. 52 .

4) Genesis 19, 21 vlgg. Jahwe zeide tot Lot: Zie ook hierin ben ik u goedgunstig, zoodat ik de stad waarvan gij spreekt niet zal onderstbovenkeeren. Berg u haastig daarin.... Daarom heet die stad Soar. 
der wereldlijke vromen kon ontdekt en genoten worden. De teruggekeerde, die goed van het land gesproken had, werd onder de leidende broeders opgenomen, die afzonderlijk met „papa” Yvon op een bovenzaal van het kasteel aten ${ }^{\mathbf{1}}$.

Nadat men met de uitrusting gereed gekomen was, reden de emigranten onder gejuich van het Huis weg. Dat een rad van den wagen brak en hen bijna in de vaart deed terechtkomen, zouden zij misschien als een kwaad ,wikteeken" aangezien hebben, zoo zij niet vast overtuigd geweest waren, dat zij de „fondateurs du grand oeuvre de Dieu" worden zouden. Zij reisden vermoedelijk over de Zuiderzee, en een gedeelte van het gezelschap lag hier voor de palen, hier, dat is in Amsterdam, want Dittelbach woonde toen in de hoofdstad. De vrienden bezochten de reizigers aan boord en brachten wat vruchten te hunner verkwikking mede. Ook Bardewisch was er bij ${ }^{2}$ ), maar Robijn, het hoofd der emigranten, twistte met hem en verweet hem, dat hij in het goddelooze Amsterdam bleef: hoe kan een rechtgeaard kind wonen onder een volk, dat dagelijks zijn vader lastert? Dat gaf groote ontstichting. Maar Lucia ${ }^{3}$ ) van Sommelsdijk, die ook medeging, was van het schip aan den wal gekomen, en nam daar afscheid. Zij greep Dittelbach's handen en zeide: „de Heer roept ons tot groote dingen en Hij geeft er ons ook een groot hart toe". Ds. Hesener, die als leeraar medę uittrok, liet de freule het woord doen, toonende genoegzaam met zijn bedeesd en neerslachtig gelaat, dat zijn geloof niet zoo groot was ${ }^{4}$ ). Nog was er Harmen Jurriaansz., die meer

1) Vergel. Dittelbach, a.w., blz. 34 .

$\left.{ }^{2}\right)$ Zoo spelt Dittelbach, a. w., blz. 53. Bardowitz, een Amsterdamsch koopman, die de Labadie's toespraken uit het Fransch placht te vertalen en, toen de huisgemeente naar Herford vertrokken was, de leider bleef van een klein groepje labadisten in Amsterdam.

3) Lucia, eigenlijk Luts, welke naam door Luts van Botnia in het geslacht Aerssens gekomen was.

4) Johannes Wesener, predikant te Britswerd en Wieuwerd, om zijne labadistische gevoelens afgezet, 6 Mei 1679, sinds opgenomen onder de ,,sprekende broeders" der huisgemeente, Acta Z. H. Syn., uitg. Knuttel V, 265, 279, 340; J. Reitsma in Vrije Fries XIII, 97-128, 142-146; N. N. B. W., VI, 773. 
uit gehoorzaamheid dan uit genegenheid medeging. Hij was vroeger kok geweest op het jacht der Staten van Friesland, dus op zee gewend, en Yvon had hem beloofd, dat hij de reizigers zou behulpzaam zijn en daarna terugkeeren. Doch toen hij er eenmaal was schreef Yvon hem, dat hij moest blijven en de kinderen des Heeren dienen. Daartegen durfde hij zich niet verzetten. „Dien man heeft mij wel aan 't hart gelegen en ik heb mij sijner gejammert" 1). Ook hem zullen wij nog ontmoeten.

In den loop van 1684 liepen de reizigers de Suriname in. Aerssens had gaarne gezien, dat zij dicht in de buurt bleven, niet te ver van het fort. Hij stelde hun voor, de nieuw aangevoerde slaven in hunne plantages te brengen, waar zij dan zouden arbeiden totdat zij verkocht waren. Meteen kon danDs. Hesener in de kerk van het fort optreden ${ }^{2}$ ). Het was een verstandig voorstel, maar de labadisten sloegen het in hun onverstand af. Israël moest alleen wonen, verre van de zondige wereld en de heidenen zouden het woord hooren, dat de christenen verworpen hadden. Zoo kwamen zij dan te wonen 40 mijlen van fort Zelandia de rivier op, daar waar de kreek Marchal in de Suriname uitmondt, ongeveer tegenover het tegenwoordige Phedra. Lucia van Sommelsdijk kreeg (of bezat reeds) daar twee plantages, de een La Providence, en daar was het dat de nieuwe huisgemeente zich vestigde ${ }^{3}$ ). De eerste indrukken waren prachtig, in drie dagen schoot het zaad op uit den vruchtbaren grond, een hof van Eden, en de aanstonds geschreven brieven brachten Yvon in verrukking.

1) Dittelbach, a. w., blz. 54 .

$\Rightarrow$ Vermoedelijk dus als huiskapelaan, want de gereformeerde predikanten zouden den labadist wel niet op hun kansel hebben toegelaten, t. w. op de bovenzaal van het Raadhuis of het Hof, die tot kerk diende. De eerste steen voor een nieuw kerkgebouw werd eerst 21 Juni 1810 gelegd. In Aerssens dagen ken ik als predikant ds. Baseliers, dien wij nog zullen ontmoeten, en ds. A. Backer, van wien in 1683 nog een brief ter synode van 's-Gravenhage inkwam, Acta, uitg. Knuttel, V, 455. Doch in 1684 was hij vermoedelijk gerepatrieerd.

3) De na te noemen labadistenkaart teekent daar ter plaatse sub 8 en 9 twee plantages en als eigenares „De suster van Sijn Excellencie Ae.” Op de groote plantagekaart van Fermin komt La Providence als no. 14 ter plaatse voor, doch toen (1765) niet meer zoo vereenzaamd als in 1684 . 
En tegen PierreBont zeide hij hoonend ${ }^{\mathbf{1}}$ ), dat hij zeker geslapen had, toen hij daar was.

Het werd haast anders. Er kwamen brieven, op hun beurt weer eenzijdig in mineur, maar toch der waarheid meer nabij. Dittelbach, nu in de huisgemeente opgenomen, hoorde de gunstige berichten aan tafel voorlezen, maar de broeders, die op verkenning waren uit geweest, gaven daar dan weer toelichtingen bij, die veel van dat schoone wegnamen. Het land heette laag, moerassig, met dichte bosschen bedekt, waarin de bijl een weg banen moest, het armste land ter wereld, alleen overvloed van suiker. Brood heet er bereid uit vergiftige wortelen, in de zon gelegd om er het vergif uit te trekken, dan geraspt en op ijzeren platen gebakken, het smaakt, alsof het zoo van den zaagmolen gehaald was. Men bespeurt aanstonds de verwarring tusschen de goede en de vergiftige of bittere cassave; de eerste geeft een voedsel, dat „het brood nog overtreft omdat het den regten smaak van kastanjes heeft", maar ook van de tweede weten de Indianen nog smakelijke koeken te bakken en het is deze bereiding, die de labadisten blijkbaar hebben gezien. Want zij raspen den wortel op een plank met scherpe stukjes steen (grage), persen het sap er uit, leggen hem eenige uren in de zon en braden hem daarna op ijzeren platen ${ }^{2}$ ). Het was niet te verwachten, dat onze Crusoë's deze kunst ook aanstonds zouden verstaan hebben en daarin vindt hun alarmeerend bericht zijne verklaring. Begrijpelijk en juist zijn hunne klachten over muskieten en mieren en over slangen, die door de huizen kruipen als thuis de muizen. In Wieuwerd bewaarde men een door de kolonisten gezonden en door hun slaven gepraepareerd slangevel van 23 voet ${ }^{3}$ ). In een dier brieven was ook sprake van twintig wilde varkens, op éénmaal gevangen, wat prachtig leek,

1) Dittelbach $t$.a.p., „hij soude hem eenigzins uyt”, wat wel ,jouwde” zijn zal.

2) Uitvoerig bij Fermin a.w., I, 59-67.

s) Dittelbach, a. w., blz. 52. Vermoedelijk de Aboma of boomslang, die 20 à 30 voet lang is, Tegenw. Staat XXXII, 556. Zie ook J. G. Stedman, Reize naar Surinamen 1799, I 230-239, over het vangen en praepareeren van zulk eene halfvolwassen aboma van 22 voet. 
maar een der broeders verhaalde, dat het vleesch dor en slecht was; men wilde er dan rookvleesch van maken, maar na weinig dagen vielen de maden er als hagel uit. Alles moet er versch gegeten worden, zout noch rook bewaart, alleen het uit Holland hun bij tonnen vol toegezonden pekelvleesch hield zich goed. Die varkens zullen wel pingos geweest zijn en ook hier speelde hun onervarenheid den labadisten parten, want wij zullen hen zoo aanstonds, door de Indianen gedroogd, pingovleesch zien eten.

Wij spraken van hun slaven. Het octrooy der nieuwe W. I. Compagnie verzekerde haar in art. 6 den begeerlijken alleenhandel in ,,swarte slaven ofte negros”. Zij kocht hen in Ardra aan de Bocht van Guinee, in Loango, in Angola, en in de jaren der labadisten bedroeg de invoer dezer rampzaligen jaarlijks een $6000^{1}$ ). Het schijnt, dat zij in den aanvang zacht voor hen geweest zijn, maar zij behoorden toch niet tot de weinigen, die in hun tijd den slavenhandel veroordeelden ${ }^{2}$ ), en waren ook weldra overtuigd, dat „men geen wille heeft van dat beestige slag van menschen als door beestige slagen". De uitdrukking doet denken aan Picardts betoog van enkele jaren vroeger dat „de zonen Chams, wanneer zij in vrijheid gesteld of lieftallig gekoesterd worden zichzelven niet weten te gouverneeren, maar bijaldien men gedurig met rottingen in hunne lendenen woont en dezelven zonder genade bastonneert, men goede diensten van hen verwachten mag, zoodat hunlieder zaligheid bestaat in slavernije" 3 ). De labadisten waren sinds als de rest en hebben aldus voor hun deel bijgedragen aan den boozen naam, dien Suriname op het

1) Memorie over den handel der W. I. C. in Bijdr. Histor. Gen. Utr. XXXV 96 vlg. 99. Voor de namen, Elminaasche enz. ook Hamelberg, De Nederl. op de W. I. eilanden I, 165.

2) In 1688 reeds een protest tegen de slavernij van enkele doopsgezinden in Pennsylvanië, Doopsgez. Bijdr. 1884, blz. 97-103. In dien geest ook Hondius, Swart register van duysent sonden, 1674, blz. 364 van den tweeden druk van 1724 . De 18de eeuw brengt eerst den eigenlijken strijd ertegen.

3) Joh. Picardt, Antiquiteiten, 1660, blz. 9. Zoo ook O. Keije, Beschrijvinge van Guijana hoofdstuk. 24, waarin ,de slaven schijnen tot arbeid geboren en volbrengen dien met vroolijkheid". 
punt van slavenbehandeling droeg,en waarvan ook vreemdelingen in krasse termen hebben gewaagd ${ }^{\mathbf{1}}$ ).

Op hunne afgelegen plantage stonden zij aan de aanvallen der Indianen onbeschermd bloot. Zij noemen hen zoo woest als de wildste „Tapoejers”, met een taal, waarin elk woord ontbreekt, dat niet behoort tot het dierlijk leven. Juist in het jaar van hun komst, 1684, had Aerssens vijf Indiaansche dorpen aan de Oostzijde van de Coppename verwoest, maar daarna vrede gesloten en hen voor vrije lieden verklaard ${ }^{2}$ ). Met dat al gingen zij natuurlijk voort zich als de ware bezitters des lands te beschouwen en het is zeer wel mogelijk, dat zij ook labadisten, die zij in het bosch aantroffen, met hunne pijlen doodschoten. ${ }^{3}$ ) Van betere verhouding zullen wij intusschen ook nog hooren.

De eerste oogst mislukte, wat ons niet verwondert bij hunne volslagen onkunde van landontginning en -bebouwing in een tropisch oord, en ook in dit opzicht doet het labadistisch waagstuk ons telkens denken aan de slecht voorbereide, onvoldoend toegeruste en dan ook jammerlijk mislukte boerenkolonisatieproef aan de Saramacca van 1845 onder de predikanten Copijn van Wilnis, v. d. Brandhof van Elst en Betting van Beets ${ }^{4}$ ). Onbekend evenzeer met alle tropische gezondheidsleer, vielen de labadisten gemakkelijk ten prooi aan allerlei ziekten, met name aan die heete moeraskoortsen, waaraan in de volgende eeuw ook de Hernhutters zoo deerlijk lijden zouden en waardoor zij als wormen over den vloer kropen of op

1) „On reproche avec raison aux Hollandois établis à Suriname, Berbice, Essequebo et sur la rivière de Poumaron un traitement dont la barbarie surpasse celui auquel les esclaves sont assujettis aux Antilles", Depêches van Thulemeyer, p. 98. „Ik ben nog in geen land geweest, waar de slaven zoo slecht worden behandeld", gouverneur Person Bonham, 14 Juli 1813 bij Wolbers, $a$. w., blz. 567. Wij weten, dat dit oordeel nog veel te zacht is.

2) J. J. Hartsinck, Beschr. van Guiana, blz. 649. Het door van Sijpesteyn Beschrijving, blz. 234, tegengesproken bericht, dat Aerssens de dochter van een Indiaansch hoofdman tot vrouw nam als bezegeling van het vredesverdrag, is toch zeer aannemelijk. Aerssens gemalin had hem niet naar Suriname vergezeld en concubinaat ging met schier elk huwelijk samen.

s) Dittelbach, a. w., blz. 56 .

4) H. Pyttersen Tzn., Europeesche kolonisatie in Suriname, 's-Grav. 1896. A. Copijn in West Indië, I, 241. Ook Van Blom in Schriften des Vereins. f. Sozialpolitik 1912, II 139, heeft deze vergelijking gemaakt. 
krukken voortstrompelden. En eindelijk, alsof deze kolonisatie alle onheilen vertoonen moest, die gemeenlijk zulke onoordeelkundige ondernemingen teisteren, het samenwonen onder zooveel ellende bracht onderlingen onvrede. „Armoede is krakeelig” en zoo kwam er haast twist onder de broeders. Reeds op reis hadden de voornamen de gelijkheid gekwetst door bv. hier en daar aan land zich te gaan vermeien „daarse de andere bloeden te scheep lieten" 1). Het was met die gelijkheid nooit geheel in orde geweest. De leiders en uitverkorenen plachten elkander te „monfrèren” en te „masoeuren”, terwijl de anderen „op zijn Fransch monsieur" heetten. Doch in dezen nood brandde het te meer op den nagel. Voorts was er ook te Wieuwerd geene volstrekte gelijkheid in de maaltijden. Hier bracht de zuster, die over de keuken ging, zuster Swem, aan den dag dat de hoofden dikwijls vooraf het beste van het eten kregen (als eenmaal Hofni en Pinehas!) en dat de anderen dan na den disch niet recht wisten of zij wat gehad hadden of niet, terwijl de leiders dan breed van den goeden zegen Gods spraken, dien hij over zóó weinig spijze gaf, waarmede toch zoovelen verzadigd werden. Toen het bedrog ten laatste openbaar werd, was de ontevredenheid groot. $\mathrm{Zij}$ begonnen den vinger in den grond te steken en te ruiken in wat land en onder wat volk zij waren en de leiders boetten er hun gezag bij in. Het slechte voedsel veroorzaakte ingewandsaandoeningen met heftige pijnen. Klisteer op klisteer kon niet tegen eene verstopping van veertien dagen, en men hoorde elkander van het eene in het andere huis krijten en kermen. Men opende sommigen na hun dood (ook op het lijk van de Labadie te Altona had men sectie gedaan). Eenigen was het vet in het lijf gesmolten en lag in korreltjes als witte hagel. Anderen hadden in het geheel geen darmnet meer, anderen nog hier en daar een stukje ${ }^{2}$ ).

\footnotetext{
$\left.{ }^{1}\right)$ Ziehier een voorbeeld van Dittelbach's verklaring van toestanden en gebeurtenissen, waartegen ik boven waarschuwde.

2) Op mijne desbetreffende vraag antwoordde men van deskundige zijde: „Het is onmogelijk om uit de verstrekte gegevens te besluiten of ook maar te gissen van welken aard de ziekte was, waaraan de labadisten leden. De kleine korrels in het abdomen gevonden zouden kunnen wijzen op tuber-
} 
Intusschen bereidde men te Wieuwerd eene tweede uitzending voor. Dat Yvon van den slechten toestand daarginds geweten heeft, kan men moeilijk betwijfelen. Dittelbach zegt, dat hij brieven van de hoofden ontving, waarin zij hen die murmureerden als rebellen afschilderden, wien het als Korach, Dathan en Abiram vergaan zou. Het is zeer goed mogelijk, dat ook Yvon niet juist was ingelicht omtrent de wezenlijke ellende, daarginds geleden, want men kan moeielijk denken, dat hij opzettelijk zijne menschen den dood tegemoet heeft gezonden. De tweede expeditie nam uit Wieuwerd veel gereedschap mede, vooral voor de suikerfabricage, veel leeftocht ook en een kistje met $f$ 3000. Jasper Dankers was deze maal de leider, een ijverig en gehoorzaam labadist, van wien niet duidelijk blijkt of hij reeds vroeger de reis gemaakt had ${ }^{1}$ ). De Amsterdamsche broeders, ook nu de emigranten begroetende, verborgen naar het schijnt hunne bekommernis niet, maar zij lachten „smuyster" ${ }^{2}$ ) over zulk ongeloof, alsof de Heer niet voor zijn werk zorgen zou. Bij de ,,soute eilanden” ${ }^{3}$ ) heeft toen een zeeroover het rijk beladen schip genomen en de menschen, naakt en berooid, op het zijne overgezet. Zoo bereikten zij Suriname en hadden zelven alles noodig in plaats van te kunnen geven en verkwikken. Op La Providence vonden zij geen Eden, maar een gasthuis, waar de kinderen tegen de muskieten met geteerde beenen rondliepen.

Het thans volgend relaas van de opstandigheid der ongelukkige kolonisten is misschien wat op gesierd door Dittelbach of zijne ooggetuigen, toch niet met leedvermaak verteld en, gemerkt den afloop der expeditie, wel betrouwbaar. Dat de hoofden den' dood van sommige „rebellen” als een straf des Heeren aanzagen ligt voor de hand. Zekere Pieter Gerritsz., een timmerman, met de tweede groep meegekomen, zag met ontzetting de ellende en de oneenig-

kels of misschien ook op de geëncepteerde moederdieren van een filaria, maar het is de groote vraag of de waarneming juist en de beschrijving goed is".

1) Dittelbach, a. w., blz. 45 vlg.

2) Ter smuig, ter smuik, verholen.

s) Kaap Verdische eilanden. 
heid. Ook hoorde hij een stervende tegen Ds. Hesener zeggen: „het berouwt mij hartelijk, dat ik ooit op uw hooge gevoelens ben ingegaan”. Of een andere: „Ga weg van mij, gij en de andere hoofden zijt het, die ons op de pijnbank gebracht hebt"'. Zuster Swem, de kookster van daareven, had een harden dood en men zeide dat dit een oordeel was over hare leugens. Men trachtte weder eene andere te doen herroepen wat zij tegen de leiders gezegd had, Pieter Gerritsz. was juist aan haar bed toen sommigen hunner daartoe bij haar kwamen en wilde zich uit bescheidenheid verwijderen. Maar zij riep: „Neen, broer, blijf hier en wees mijn getuige!" En toen de anderen er sterk op aandrongen, dat zij zou bekennen onwaarheid gesproken te hebben, zeide zij: „Ik heb de waarheid gezegd, ik ga tot God en wat zou mij bewegen te liegen." Meteen keerde zij zich naar den wand en gaf den geest. In dit alles is veel tragiek en de beschrijving ervan niet zonder ontroering. Het sarcasme ontbreekt niet: deze laatste woorden verschillen wel veel van Yvons „Fidelle narré des dernières paroles et dispositions", die hij ook in het Engelsch en Italiaansch heeft doen overzetten, zegt onze auteur. Wat ze inderdaad doen!

Pieter Gerritsz. was een der eersten, die besloot naar het vaderland terug te gaan, niet dan na ook zelf zwaar ziek te zijn geweest en op krukken gereden te hebben. De hoofden zochten hem te overreden om te blijven. Dittelbach zegt, omdat zij wel wisten, dat zijne terugkeer daarginds ,een stank zou geven.” Misschien. Het is even mogelijk," dat zij nog in de kolonie en in ,le grand oeuvre de Dieu"' geloofden en het niet verlaten wilden zien. De vrouw van Robijn, Sara van der Pol, trachtte Pieter te overtuigen dat hij zich bezondigen ging aan de gemeente des Heeren, maar, toen hij volstandig bleef, begon zij te vloeken en te zeggen, dat zij wilde dat hij op de baar lag en dat de Heer zou maken, dat de Turk zijn schip nam. Doch hij hield vol, ging terug en Sara is kort daarna gestorven. Pieters bevindingen op Thetinga-State en hoe men hem in het blauwe kamertje afzonderde en trachtte voor de gemeente te behouden, opdat niet door zijne verhalen in 
de wereld „den bommel uyt sou breken”, aan dat alles ga ik voorbij. Op La Providence ging het al ellendiger, Robijn keerde ook terug, anderen namen insgelijks de „passe poort onder de voeten" en waagden zich in dezen onveiligen tijd liever op zee, dan daar langer te blijven. De dood raapte voor en na de kolonisten weg, in 1687 o. a. Ds. Hesener, voor het laatst verneemt men wat van de plantage in 1719. In dat jaar werd zij verkocht door Caspar Robijn en zijne echtgenoot Marthe Yvon, wonende op het slot te Wieuwerd en Vincentia van der Haar te Leeuwarden. Robijn kennen wij al. Marthe was stellig de dochter vanYvon en juffr. Martini ${ }^{1}$ ). Vincentia was de dochter van die Mad.elle van der Haer, die de labadisten in haar huis in Den Haag ontvangen, hen daarna te Amsterdam bezocht had en hen eindelijk met drie harer dochters naar Herford gevolgd was. Sinds waren zij leden der huisgemeente, de moeder stierf Juli 1678, eene harer dochters, getrouwd met Dulignon, overleed 28 Dec. 1686 in het kraambed, 31 jaar oud ${ }^{2}$ ). Er was nog eene Emilie en dan deze, naar Leeuwarden verhuisde, Vincentia. Blijkbaar beschouwde de gemeenschap zich dus eigenares der plantage. Was Lucia, na den moord op haar broeder in 1688 teruggekeerd en had zij haar land den labadisten geschonken? Viel deze verkoop in 1719, in 1732 ging de gemeente te Wieuwerd onder, in 1733 lieten de erven van Hans Willem baron van Aylva, den toenmaligen eigenaar van Waltha-State, het slot afbreken en het heerlijk geboomte vandalistisch rooien.

Van de lotgevallen der labadisten in Suriname is nog een bericht tot ons gekomen. Op de Koloniale Bibliotheek te Paramaribo bevindt zich in handschrift het journaal van een reis, die eenige kolonisten van La Providence ondernomen hebben naar de Boven Cottica en de Couremoetibo. Ds. J. W. C. Ort gaf het indertijd uit als feuilleton in het Protestantenblad voor de kolonie Suriname

1) Koelman, Histor. verhaal, blz. 25; Dittelbach, a. w., blz. 24.

$\left.{ }^{2}\right)$ Yvon, $a . w$. p. 50-60, 114-139. De verkoop volgens Mr. Bijlsma in W.-I. Gids, Oct. 1921, blz. 332. 
van 8 Mei 1920 no. 19 tot 21 Augustus no. 33. Door vriendelijke beschikking van de autoriteiten te Paramaribo heb ik het Hs. te Leiden kunnen raadplegen en met die uitgave kunnen vergelijken, die zonder noemenswaardige afwijkingen bleek. Van enkele aanteekeningen van Ds. Ort heb ik dankbaar gebruik gemaakt. Bij het manuscript bevindt zich een kaart van de gronden langs de Suriname, Commewijne, Cottica en Couremoetibo, waarvan de heer Fr. Oudschans Dentz zoo vriendelijk was mij eene fraaie kopie ten gebruike af te staan. Als jaar der reis wordt 1686 aangegeven, als eerste dag Maandag 20 Mei. Dit klopt. Doch een week later spreekt het journaal van Dinsdag 27 Mei. Zóó was het in 1687. Intusschen is dit eene vergissing en geeft geen genoegzamen grond het jaar 1686 los te laten, waarvoor trouwens ook andere data in het journaal pleiten. De schrijver noemt zijn naam niet en men kan dus allerlei gissingen maken en bv. aan Hesener denken. Maar behalve, dat hij dan wel een zeer slechten stijl zou gehad hebben, spreekt de auteur van zijn aanstaand vertrek naar 't vaderland, wat voor Ds. Hesener wel wat snel zou geweest zijn. Gelukkig geeft hij wel de namen zijner tochtgenooten t. w. Robijn, dien wij reeds hebben ontmoet, Harmen Jurriaensz. ons ook reeds bekend ${ }^{1}$ ) en Hans Simon. Hij zal wel dezelfde zijn, van wien wij eene vroegere aanteekening van Yvon in zijne Narré hebben: „Hilletje, la fille de notre frère Hans Simons notre charpentier." Voorts gingen twee negerslaven mede en het Indiaansche jongetje Pito, dat Indiaansch ${ }^{2}$ ) en Hollandsch spreken en dus als tolk dienst doen kon.

De schrijver begint dan te vertellen, dat La Providence 20 mijlen (lees 40) boven het fort aan de linkerzijde der rivier ligt ${ }^{3}$ ). De plantage was niet geschikt om de tweede groep te ontvangen, waarvan de overkomst reeds besloten was. Daarom had men het vorige jaar al eene onderzoekingsreis naar de killen en landen bij de Marowijne en

\footnotetext{
1) Er staat Herman, Jurien, de komma blijkbaar eene vergissing.

$\left.{ }^{2}\right)$ Gedrukt: sijn diaensch; Ms. yndiaens.

s) Het fort nl. Zeelandia en dus Paramaribo. Aan de linkerzijde t. w. van den mond af.
} 
de kreek Coeremoetibo ondernomen, thans wil de schrijver vóór zijn vertrek naar het vaderland en omdat onze waarde herder Yvon het zeker zou goedkeuren gaarne op een tweede expeditie medegaan, om daardoor ook voldoening te geven aan die hem gezonden hadden ${ }^{1}$ ).

Men vertrok dan in de bark Maandag 20 Mei 1686 om 8 uur, maar raakte vast op een zandbank bij de Cassipoere kreek ${ }^{2}$ ). Daarom verliet schr. het schip en ging met een neger in de kano vooruit, om alvast aan Samuel Nassy, die daar in de buurt woonde ${ }^{3}$ ) het model van een zaagmolen te brengen, dat Hans Simons hem beloofd had, om bij een anderen jood ${ }^{4}$ ) een oorkussen te halen en om aan Ds. Baseliers de zalf over te reiken, die broeder Huybrecht voor hem gereed gemaakt had. Ds. Baseliers woonde op Palmeneribo ${ }^{5}$ ), maar was juist op dienstreis naar de Commewijne. Alleen zijne vrouw was thuis en zijne dochter, die enkele vriendinnen uit de stad over had, over wie schr. zich zeer ergerde omdat zij „volkomen mondains" gekleed waren ${ }^{6}$ ). Voor eene harer, juffr. Broens nam hij op zich een brief aan haren vader op het fort te bestellen. Toen zocht hij met zijn kano de bark weer op, die voorbij de Cassiepoere op het verloopen van den vloed wachtte. Men reisde verder en ankerde 's avonds een goed stuk beneden Zandpunt ${ }^{7}$ ).

Dinsdag 21 Mei kwam men te 3 uur te Paramaribo aan. De schrijver ging naar den heer d'Alibert op de gouverne-

1) Uit Holland. Hij zou dus voor de tweede kolonie vooruitgezonden zijn, wat verbiedt aan Wesener te denken.

2) Casseapori op de kaart bij Hartsinck, a.w. blz. 521.

3) Samuel Cohen Nassy, die in 1682 den Portugeeschen Joden een groot stuk land of Savanne geschonken had, waar 1685 een prachtige synagoge verrezen was, centrum spoedig der gemeente, Joseph Wallach, Beschrijving.... van het eerste jubelfesst der synagoge, Amst.1786. Zijne plantage op onze kaart no. 21 , vergel. no. 15.

4) Misschien Elia Elii, no. 20.

s) Op onze kaart no. 25 „Dame Baselie”; op de plantagekaart van Fermin no. 52, Palmenisebo.

6) Mondeyns, mondeynsheit bij Dittelbach a. w., blz. 21, de kleeding, blz. 37.

7) Volgens Ms. Bij Torrarica aan den linker oever, waar enkele joodsche planters woonden en in 1672 hunne eerste synagoge gebouwd was. 
mentsplantage ${ }^{1}$ ) om „tayer ${ }^{2}$ ) en yams” op te doen en had daarna een lang gesprek met zekeren Cyprianus die de wereld verlaten en den Heer dienen wilde, maar zich in die wereld zóó geëngageerd vond, dat hij geen apparentie zag om van haar ontslagen te worden, want de genade in hem was nog niet krachtig en triumphant genoeg. Deze man, kommies bij 's lands magazijnen, leverde hun uit den voorraad zes roggebroodjes van een schelling het stuk. Den volgenden dag brengt schr. nog een bezoek aan zijn nicht Clefson, wier man naar de Commewijne was en die hem ten eten vroeg, wat hij aannam, hoewel zij eene mondaine en zeer verdorven was. Er had een gerucht geloopen, dat er een Hollandsch schip in 't gat ${ }^{3}$ ) lag en met den vloed zou opkomen. De labadisten verheugden er zich over, omdat het, zooal geen broeders, althans provisie en brieven brengen kon. Maar misschien was het een kwaad schip, gelijk de roep ging dat er zeeroovers op de kust waren, dus zendt de gouverneur luitenant Couper met eenige soldaten op eene landsbark op kondschap uit. Middelerwijl trokken onze reizigers verder, om half vier was men aan den mond van de Commewijne (waar het fort Amsterdam toen nog niet lag) ${ }^{4}$ ) en kwam met den vloed nog wat hooger dan de Peersenkreek ${ }^{5}$ ).

Donderdag 23 Mei gaat men 's ochtends 3 uur verder, komt 6 uur voorbij de kreek Matapy ${ }^{6}$ ), om 7 uur laat men de Commewijne aan de rechterhand haren loop vervolgen en slaat links de Cottica in. Bij de samenvloeiing zagen de reizigers een groot stuk bosch geveld, de plek waar de

1) Fermin, $a . w . \mathrm{I}, \mathrm{xx}$, kleine landerijen no. 2.

2) Igname of Teye, soort van aardappel, Tegenw. Staat XXXII 538, 616 vlg. De bereiding en het gebruik bij Fermin, a. w. I, $136 \mathrm{vlg}$.

3) D. i. bij Braampunt aan de zee.

4) Het is van 1747. Gezicht en platte grond bij Stedman, a. w., I, 180.

s) De heer Ort teekent hier aan: oude naam voor Orleans-kreek. Beter is Orelijne kreek, bij verbastering Hoer-Helena-kreek genoemd, zegt Hartsinck a.w., blz.575. Of andersom, vermoed ik eerder. „On the bank of this creek flourished in days gone by the still famous Helena, a mulatto syren, whose dusky charms are said to have rivalled in their mischievous effects if not in other respects those of her Grecian namesake", W. G. Palgrave, Dutch Guiana 1876, p. 117.

$\left.{ }^{6}\right)$ Of Matapica aan de linkerhand in 't opvaren. Bij Stedman a. w. I 184, Matapaca. 


\section{NAMEN DER PLANTERS EN PLAETSEN DER PLANTAGIES OP HARE NOMBERS GESTELD.}

in de Suriname

1. $d^{\prime} h^{r}$ Muninx

wintsaegmolen.

2. 't Fort Zeelandia.

3. Kerk.

4. Plantage v. d. Sariete.

5. 't Fort Para.

6. Kerk.

7. Mesa.

8. De Suster.

9. van Sijn Exellencie Ae.

10. Joseph Nassy.

11. Bedloo.

12. Daeght.

13. da Costa.

14. Wilden Carbet

15. Samuel Nassy.

16. Wilde Carbet.

17. Abr. di Pina.

18. Jaq. da Costa.

19. Di Silva.

20. Elias Elij.

21. Samuel Nassy.

22. Goods.

$+$

24. Para.

25. Dom: Baselie.

26. $d^{\prime} h^{r}$ Scherpenh.

27. Sune da Costa

28. Serfatijn.

29. don Pedra.

30. de Fonseca.

31. Rabbij Arias.

32. Jacob Nassij.

33. David Drage.

34. Davilaer.

35. Brugman.

36. M. Maertens.

37. $\mathrm{d}^{\prime} \mathrm{h}^{\mathbf{r}}$ Chattillon.

38. B. Perduin.

\section{Commewijne}

39. Jan Hart.

40. Fis Muninx

41. Gasper.

42.

43.

44. Caes moefer.

45. Darbij.

46. Bruijn.

47. Matthij. in de Commewijne

48. 't Fort de Commewijne.

49. Secr. de Graef.

50. Makentof.

51. B. Perduijn.

52. Bruiningh.

53. Cor. Snelleman.

54.

55.

56. Bon: en Boogner.

$57 \mathrm{~d}^{\mathrm{h}} \mathrm{h}^{\mathrm{r}}$ Vredenborg.

58. van Vollenhoven.

59. Jan Codercq.

60. Calison.

61. Ketelaer.

62. Clais de Camp.

63. Albertijs Cranc.

64. La Para.

65. Aron di Silva.

143. Pan Lam.

144. Maerten Jacob Jz.

145. Codercq

66. Moris.

67. Van Lagen.

68. Mogge.

69. Jan de Backer.

70. Jacob de Kaijser.

71. Borggraaf.

72. Burgm: Muninx

73. Charle Faket.

74. Jan de Neel.

146. Jan Meerman.

75. Frd: v. Ruijn.

76. Anth. v. Scheur.

77. Ouden hoek.

78. van der matte.

79. Tissou.

80. Abel Marine Jz.

81. Schoemaker.

82. Cor: verhart.

83. Frimaat

84. d'hr. Thijssen.

85. Bar. Reynier Jz.

86. Meulenaer.

87. d'h ${ }^{r}$ Norden.

88. Capt : gores.

89. greenwood.

90. $d^{\prime} h^{r}$, verBoom

91. Philebrecht.

92. Pieter Roijs.

93. Roose Ceeke.

94. Pere v. Lorsen. in de Commewijne

95. Fanne Faux.

96. La Croix.

97. Jan Tuisseur.

98. Ade Sandrij.

99. Jan Starrenberg.

100. van Reuven.

101. Bolle.

102. W. de Bruijn.

103. Adriaen Jz.

104. van Schendel.

105. Pieter Jasper B.

106. Jan Ridderbach.

107. Andr: de haan.

108. N. Snelleman.

$$
\text { Perka. }
$$

109. B. de Langelaise.

110. Schedam.

111. de Lisle deveaux.

112. La Fortune.

113. Sacre Bri.

114. Dantrec.

115. Weijers.

116. Den Fort.

117. Collecto metric.

118. Jacob Stabij.

119. M. dacrit.

120. Jan Davits.

121. Galais Britton.

122. Willem Davits.

123. Robert Bare.

124. P. van der hooft.

125. W. de la place.

126. Belletof.

127. Jacob Jz.

128. Bentarius.

129. Bachman.

130. d'hr Wobma.

131. van der poele.

132. Bistorius.

133. Bao.

Cotteca.

134. Bas.

135. uilsma

136. Caert.

137. Frans daems.

138. Overschelde.

139. Wilde Carbet.

140. P. de Later.

141. P. Cousijn.

142. Forel. 


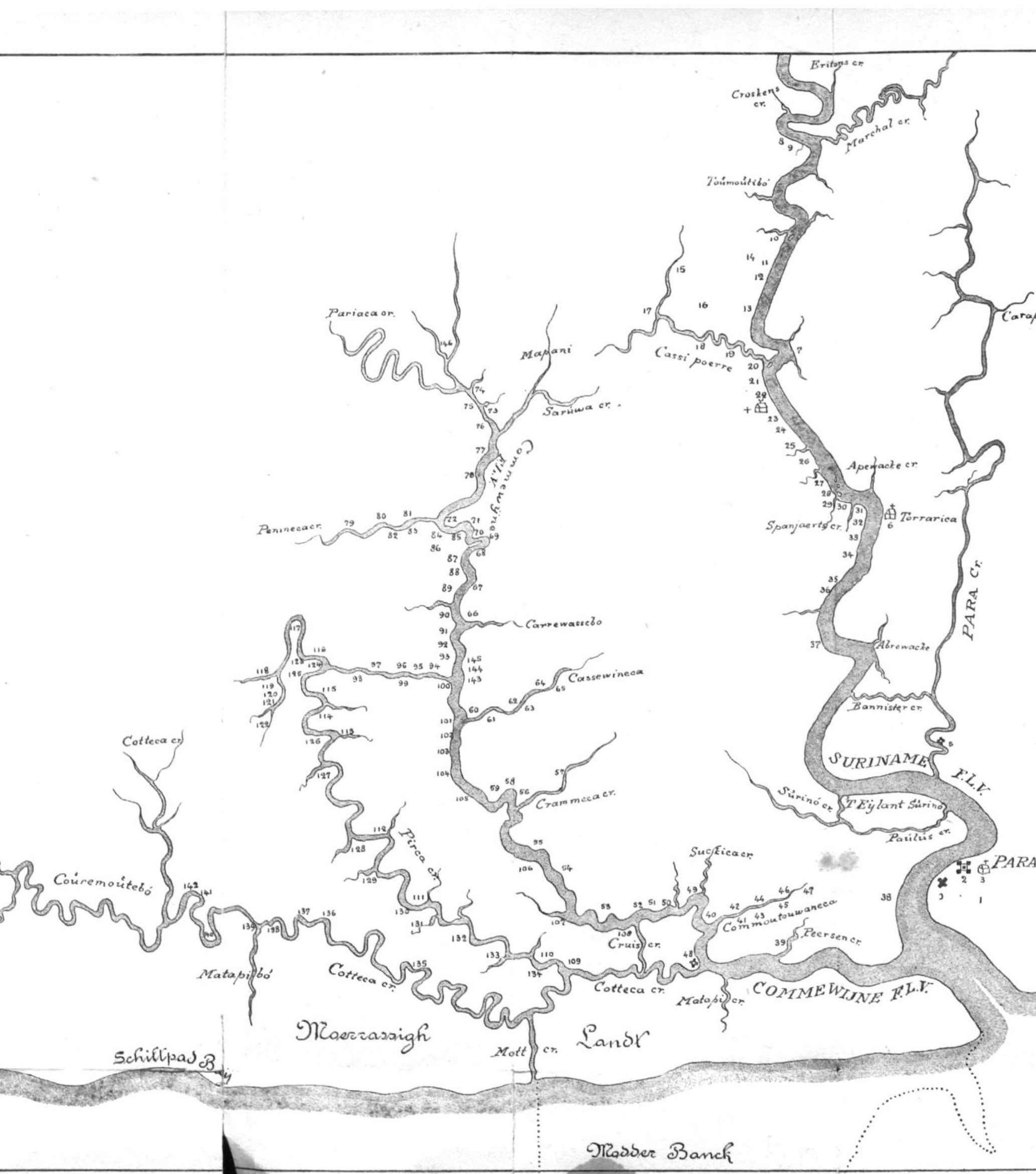


gouverneur het fort wilde bouwen, dat naar hem Sommelsdijk zou heeten ${ }^{1}$ ). Des avonds kwam men bij de Pirca kreek ten anker ${ }^{2}$ ). Vrijdag 24 Mei was het half vijf vloed, men roeide om 7 uur voorbij de Pirca rechtsch, om 9 voorbij de Motkreek linksch en kwam half elf bij ebbe ten anker. Om 5 uur was het weder vloed en kon men voortgaan tot middernacht. De Cottica bleek tot langs de oevers diep, soms elf en nooit minder dan zes vadem water, dat bruin en zwart voortstroomde, zonder klippen. Doch de muskieten waren hier, met den regen, de groote plaag.

Zaterdag 25 Mei trok men onder zwaren regen verder en kwam te middernacht ten anker wat beneden de plantage van zekeren Uilsma ${ }^{3}$ ). Daar kwam men Zondag 26 Mei om 8 uur aan. Onze labadisten zagen een aantal vaartuigen op de rivier, met Engelschen bemand, en dachten dat er ergens kerk zou gehouden worden ${ }^{4}$ ). Doch het bleken de bruiloftsgasten van de eigenares der plantage ${ }^{5}$ ) te zijn, die hertrouwde. Zij was vroeger een kwakerin geweest, maar nu zoo ijdel en mondain geworden in kleeding en manieren, ofschoon al over de 50 jaar, dat de labadisten, die op dat punt zeer gevoelig waren en zich reeds aan juffr. Baseliers en later aan juffr. Clefson geërgerd hadden, maar liever verder roeiden, na alleen naar den weg gevraagd te hebben. Tegen den middag bereikten zij de plantage van Frans Daems ${ }^{6}$ ). Zij vonden den man niet thuis, hij was op de schildpaddenvangst, die daar, bij de Schildpadbaai zeer talrijk en wel 300 pond zwaar zijn.

$\left.{ }^{1}\right)$ „The selection of this post will ever remain a proof of the administrative no less than of the military talents of Van Sommelsdijk, Palgrave, a. w., pag. 115 .

$\left.{ }^{2}\right)$ Of Cruis kreek op onze kaart.

3) Dat moet op onze kaart no. 135 zijn, waar de legenda den naam Uilsma heeft, Ort heeft Ulsmat. Het was de eerste plantage sinds hun vertrek van Paramaribo. Men ziet hoe weinig er toen nog langs de Cottica waren.

4) D. w. z. godsdienstoefening. Een kerkgebouw der hervormden kwam er bij fort Sommelsdijk en veel later, 1721, zou er een komen daar, waar de Perica in de Cottica vloeit, voor de bevolking der toen talrijke plantages. De gemeente ging echter 1797 te niet (de laatste predikant was J. C. de Cros.) W. Boekhoudt, Uit mijn verleden, Winschoten, 1874, blz. 121, zag nog de bouwvallen der kerk, met kreupelhout bewassen.

$\left.{ }^{5}\right)$ T. w. no. 136 op onze kaart.

6) No. 137 . 
Zijne vrouw was op het punt van te bevallen. De labadisten bespeurden aanstonds dat zij iets dat van den Heere was in het hart had. Ook de vroedvrouw was niet zeer aanstootelijk, maakte een goeden indruk. $\mathrm{Zij}$ was van Bremen of Hamburg en in het Luthersche gevoelen. Nog was er een meisje van een jaar of veertien en de moeder zeide hun, dat zij het gaarne bij de labadisten zag opgevoed. Doch zij moesten verder en kwamen 's avonds bij de plantage van zekeren Overschilde ${ }^{\mathbf{1}}$ ). Zij zochten hem Maandag 27 Mei op. De man was van Curaçao gekomen, waar de grond echter schraal en uitgeput was, en had zich hier met 3 zonen nedergezet, welk voorbeeld ook zekere heer Timmerman welhaast, aan het einde van de Cottica, volgen zou. De reizigers hoorden van hem allerlei over de goede manier van maïs te bewaren. Dan bij opkomenden vloed, 8 uur, toog men verder, zeilende nu, want de bark had ook zeilvermogen, en kwam voorbij een Indiaansch dorp. Daar gaven zij een bijl voor wat gedroogd pingovleesch ${ }^{2}$ ) en zeilden voorts met goeden wind tot voorbij de plantages van Pieter Cosijn en mons. Forel ${ }^{3}$ ), die aan boord kwamen en alle hulp beloofden. Het regende hard. Even na middernacht bereikte men de scheiding van Cottica, rechtsch, en Coeremoutibo, linksch, die daar in de Cottica vloeit, na haren grooten bocht naar het Noorden $\left.{ }^{4}\right)$. Men ging de Coeremoutibo in, het was nu Dinsdag

1) No. 138 op onze kaart.

2) Vergel. boven, bl. 8, pinko, pingo, (Dicotyles labiatus) pecario, navelvarken, goed wildbraad, Tegenw. Staat XXXII 488 vlg., 553 vlg. Fermin, $a$. $w$. II, 79 vlg.

s) Nos. 141 en 142

4) Hartsinck, a. w., blz. 521 de kaart. Stedman a. w. I, 295 vlgg. beschrijft ook de Coeremoutibo, zonder natuurlijk van den tocht der labadisten te weten. In deze streken, aan de Patamacca, de Coeremoutibo en de boven-Cottica, noordelijk waarvan vroeger de Hernhutters hun zendingsstation Wanhatti hadden, predikte nog kortgeleden de boschneger Atjarinsi Koelè, een Saramaccaner, dat hij de god derDjoeka's was en dat men het Christendom te keer moest gaan, een marronsche Radbout of Wittekind. Zulke tegenstanders waren ook gramman Ossesi op Drietabbetje aan de Tapanahoni (overl. 1915) en Bakoe onder de Djoeka- of Aukanegers van de Suriname, daar waar de Sarakreek uitmondt en de zendingspost Koffiekamp ligt en Brohokomakka. Deze beide laatsten overleden in 1910 en Atjarinsi leerde, dat hij hen gedood had, omdat zij hem niet wilden aanbidden. Vergel. H. Weiss, Vier maanden in Suriname, 1915, blz. 50-57 (die 
$28 \mathrm{Mei}^{1}$ ), voer dapper verder tot namiddags 5 uur, toen kwamen Cosijn en Forel hen achterop pattelen ${ }^{2}$ ) in hun kano en logeerden aan boord der bark.

Woensdag 29 Mei begon dan de eigenlijke onderzoekingstocht. Om 8 uur 's morgens gingen de reizigers aan den linkeroever der kreek aan land en vonden daar goeden, vetten kleigrond, van 't gele naar 't bruine strekkenkende en vet genoeg. En op het einde van den dag kwamen zij bij het eerste hoogland, dat „onze frères” het vorig jaar bezocht hadden. Dat was dus 1685 geweest en bewijst dat de labadisten reeds zoo spoedig na hunne vestiging op La Providence naar anderen grond hadden uitgezien. Cosijn en Forel sliepen dien nacht aan land op zijn Indiaansch. Donderdag 30 Mei bemerkten zij dat zij dat hoogland al voorbij waren geroeid, gingen echter verder en kwamen aan de kreek Waneka (of Wana) die naar de Marowijne doorloopt. Een sterke stroom met zwart water viel uit die kreek in de Coeremoutibo. Vrijdag 31 Mei voeren Cosijn en Forel de Wana in om te zien of zij ook Indianen zouden aantreffen, die de reizigers naar de $\mathrm{Ma}-$ rowijne konden geleiden. Onze auteur had voorgesteld om de bronnen van de Coeremoutibo te gaan zoeken, die wel in de nabijgelegen bergen ontspringen zou. Dus roeiden zij tegen den stroom op, het water werd helderder, maar na tallooze bochten kwamen zij aan een bosch in de rivier, d. w. $z$. de rivier ging tusschen de stammen door, totdat zij er zich in verliest, zoodat de schr. gelooft dat zij uit die „byrebires” ontspringt ${ }^{3}$ ). Hunne frères hadden het vorig

den gramman als Brokkamaka spelt); dez., Ons Suriname, 1911, blz. 7078; Ad. Schulze, Abrisz einer Geschichte der Brüdermission, 1901, S. 188; W. $\mathrm{J}$. van Lier, Iets over de boschnegers in de boven-Marowijne. Overigens L. C. van Panhuys, The heathen religion of the Bush-negroes, Actes du Congres intern. de l'hist. des relig. à Leide 1913 en L. Junker over dat zelfde onderwerp in W. I. Gids, Juni-Aug. 1925. Zendeling Voullaire in zijn Land, Leute und Missionsleben in Suriname, Hernhut, 1925, dat ik nog niet zag.

$\left.{ }^{1}\right)$ Hier begint de foutieve dateering in het Ms., waarvan ik reeds sprak, dat zegt $27 \mathrm{Mei}$. Ik zal dat verder niet opzettelijk aanteekenen.

$\left.{ }^{2}\right)$ To paddle; en daarvan pattelen.

s) Mijn vriend, prof. Hesseling, had de goedheid mij in te lichten: biribiri Negereng. voor lang gras of biezen die op moerassige plaatsen groeien; de etymologie is niet duidelijk, misschien, maar niet waarschijnlijk, eene ver- 
jaar maar drie hooge plaatsen aan den rechter of zuidkant der kreek gevonden, zij zagen thans aan den noordkant verscheiden hooge landen met goeden grond en met kostelijk bouwhout begroeid. Ook aan den zuidkant zagen zij eene uitgestrekte vlakte met witte klei en bouwhout. Er was daar ook reeds eene zagerij van een jood, die aan de Cottica woonde, en er lagen gezaagde wanenhouten planken, waarvan men de braziliaansche suikerkisten maakt. Wij gelooven onzen schrijver gaarne, wanneer hij ten slotte zegt: vermoeid en vuil kwamen wij weer aan onze bark.

Zaterdag 1 Juni bezochten zij weder het eerste hoogland van gisteren, vlakke kleigrond, dan een langzaam opgaande berg, bouwgrond en veel cabeshout ${ }^{\mathbf{1}}$ ). Zij zouden nog verder gegaan zijn, maar Forel kwam hun in zijn kano melden, dat er wel 6 of 7 booten met Indianen aan hunne bark lagen. Zij vonden daar een dertigtal menschen, die hen over de Wana, de Marowijne en de Amanibo inlichtten. Om de lange reis door de Wana-kreek naar de Marowijne besloten zij om later liever buitenom d. i. over zee naar hier te komen en thans om te keeren. Fr. Herman (Jurriaansz.) leed veel pijn van zwerende vingers en kon hen toch niet meer vergezellen, terwijl onze schrijver zich in de geneeskunst weinig ervaren noemt en ook alleen maar wat basilicum (pikzalf) en pleisters bij zich had. Dus wilden zij maar liever naar Paramaribo afzakken om te zien wat de Heere daar verder met hen voorhad. Na het vertrek der Indianen voeren zij de kreek weer op en kozen een plaats voor een toekomstige watermolen. De diepte der Coeremoutibo was hier 2 vademen, de breedte nog 90

dubbeling van biezen. De beteekenis in elk geval biezenland, rietland. Moeras is in 't Negereng. swampoe, verdronken land heet verzuipi gron. Aldus zegt ook Tegenw. Staat XXXII, 534: moerassige gronden waarvan het grootste deel wel $\frac{3}{4}$ jaar onder water staat. Hartsinck $a . w .$, blz. 580 vlg. insgelijks: tusschen de Coeremoutibo en de Marowijne ligt een groot biezenland met 4 of 5 voet water in den regentijd, wanneer het een meer wordt waarin men gemakkelijk verdwaalt, zoodat men Indianen als gidsen dient te hebben. Hij noemt de expedities in deze streken van Louis Nepveu in 1747 en van Carel Philipp Spellenaar in 1767, maar weder niet de labadisten, bewijs ten overvloede hoe onbekend hun tocht gebleven was.

1) Misschien kopie-hout, een bastaard-ceder. Voor de houtsoorten $T e$ genw. Staat XXXII, 551 vlgg. Fermin, a. w., I 218-228. 
voet, klaar water, zoodat zulk een molen altijd genoeg zou hebben. Deze plek scheen hun dan ook in het bijzonder voor eene plantage geschikt. Den volgenden dag, Zondag 2 Juni, namen zij toch de terugreis nog niet aan. Met wat maïsbeschuit als proviand gingen Robijn, Hans Simon en onze schrijver met een neger 6 uur 's morgens in een kano de Wana-kreek in. Na $2 \frac{1}{2}$ uur kwamen zij weder aan een verdronken bosch, waar het killetje dwars doorheenliep, zoo dicht bewassen dat men er niet door kon zien en scherp moest opletten, dat men geen takken tegen zijn gezicht en lijf kreeg, al maar bukkende, zoodat rug en lenden wel vermorseld schenen door dat gedurig zich krommen.Stiet men aan een tak dan was er een regen van houtluizen ${ }^{1}$ ) en mieren, die hen zeer ,,incommodeerden”. Door duizenden takken moesten zij zich aldus een weg boren, tegen een harden stroom en regenvlagen in, doornat eindelijk. De Indianen hadden wel eene opening gemaakt, maar zoo nauw dat het meer voor kruipen dan voor varen was. Dáarna kwamen zij aan eene opening, breed als de Leeuwarder vaart, die zij daarom (in deze wildernis het Friesche heitelân gedenkend) ook zoo noemden, maar een goed half uur later kwam de kil weer onder zoo dik geboomte, dat zij den dag er niet door zien konden. Eindelijk bereikten zij de byribiris, voor 't oog zonder einde en voeren over deze verdronken weiden, met gras begroeid, een voet water en vaste kleigrond, vele palmboomen recht als stralen, kleine eilandjes met bosschages, aangenaam en vermakelijk verschiet voor het oog, waartusschen men „als in een perspectief" de groene, effen velden tot in het oneindige zich zag uitstrekken. $\mathrm{Nu}$ werd de kil nauw en ondiep en zij noemden haar daarom de Langestraat of het Langedelft. Het was zoo prettig, alsof men in Holland of Friesland in een sloot door de weiden voer. Aldus onze schrijver met een echt vaderlandsch beeld van gezellige rust. Aan weerszijden verhieven zich weder hooge palmboomen, een waarvan zij met hun merk teekenden, opdat, wanneer zij later over zee naar de Marowijne kwamen en

1) Over houtluizen Stedman $a . w .$, III, 340 vlgg. 
vandaar de Wana invoeren, zij zouden kunnen zien hoever zij geweest waren. Doch nu keerden zij dan ook om. Er was niemand, die hen bij de Indianen als tolk kon dienen, de proviand was op en hunne liefde liet niet toe, dat zij fr. Jurriaansz. nog langer in de bark en in angst ${ }^{1}$ ) lieten. Zoo besloten zij dan naar de bark terug te keeren, het ging nu stroomaf, sneller dus, maar ook met grooter gevaar van tegen de boomen aan te varen. Vaak vielen zij omver. Eindelijk om 4 uur ,gerochten” zij aan boord ${ }^{2}$ ).

Maandag 3 Juni lichtten de ontdekkingsreizigers dus de dreggen om naar het fort af te zakken, nadat zij nog een gesprek met Indianen van de Amaribo gehad hadden, „kleyne Pito ons vertolkende”. Bij het laatste hooge land stapten zij nog even uit en noemden het Lokusberg om het vele lokus-hout dat er groeide en dat voor rollen in den suikermolen zou kunnen dienen. Ook tapten zij van één boom wel 2 pond lokus-gom. Op een anderen lag een tijger, die echter vluchtte bij hun nadering. In den mond van de Wana-kreek vingen zij een landschildpad en een soort schelvisch, die hun goed smaakten en den volgenden dag, Dinsdag 4 Juni, waren zij de Coeremoutibo weer door en om 4 uur in de Cottica. Spoedig kwamen zij nu voor Forel's plantage, die hen vriendelijk ontving en, hen na hun vertrek achterna roeiend, nog een levenden haan ${ }^{3}$ ) in de boot wierp. Wat verder zagen zij Cosijn, die aan boord kwam en een „dram ${ }^{4}$ ) en een koekie” kreeg, waarmede hij zeer blijde was. Daarna ankerden zij voor de plantage van juffr. Campets. Haar dochter, eene weduwe en juist bevallen, stond te hertrouwen met Pieter de La$\operatorname{ter}^{5}$ ), zoon van Jan de Later, kuiper te Middelburg. Mochten zij daar in de buurt komen wonen, dan zou de vrouw

1) Ms. hanghste.

2) Vergel. „die nije mare door welcke ghi sijt ut gherocht”, er uit geraakt, verlost, Een devoot ende profitelick boecxken 1539, 1889, no. 67, 20, 3 vlg. Vergel. F. C. Wieder, De Schriftuurlijke liedekens, 1900, blz. 126-129.

3) Ms. heeft aen. Dit en het bovengenoemde hangst voor angst is streektaal, die op het spoor van den schrijver zou kunnen brengen.

4) Dram of kilduivel, gestookt van het schuim op de suikerketels, na eene tweede overhaling sterk als rum, gold voor een „gezonden dranck".

s) No. 140 op onze kaart. 
gaarne haar zoontje bij hen doen inwonen om de chirurgie te leeren. Men ziet, hoe de roep van ver te zijn in genees-, heel- en verloskunde, die ook van de labadisten op Thetinga state uitging, reeds tot de Surinaamsche wildernis was doorgedrongen. Doch hier hadden zij geen Van Deventer! Middernacht, dus Woensdag 5 Juni, gaat ons journaal weder voort, roeiden wij verder en kwamen 's ochtends bij Frans Daems, die „sich seer koelties hieuw”. Wij vernemen echter niet waarom. Wel, dat de vrouw voor enkele uren bevallen en zeer zwak was. 's Avonds tusschen licht en donker dan de plantage weer van Uilsma, waar de labadisten een arm meisje, dat naar Paramaribo moest, aan boord namen. Donderdag 6 Juni zette de eb in, waarvan de reizigers haastig gebruik maakten, ook omdat de vingers van fr. Harmen erger werden. Bij heldere maan waren zij 2 uur na middernacht weder aan de Pirca-kreek, Vrijdag brachten zij het met goeden wind tot vóór in de Suriname, omdat zij den vloed doodgezeild hadden en Zaterdag 8 Juni lagen zij 's morgens vijf uur beneden fort Zelandia ten anker. Voor Paramaribo vonden zij het schip van Jan Booms van Vlissingen, waarvan Uilsma hun de aankomst al verteld had. Ook lag er een Engelsch scheepje van Boston. Schipper Booms bleek te hebben medegebracht brieven van het Huis des Heeren (te Wieuwerd), een van juffr. Agatha Achijn aen fr. Harmen Jurriaansz., maar dan ook zes tonnen Iersch vleesch, een brandstuk (ton) met stokvisch, een oxhoofd Turksche boontjes, een met grauwe, een met witte erwtjes, met nog een vierkant „kassie” (kaasje?). Zij waren er zeer blijde mede, omdat het zoo bijzonder noodig was en zij het nu meteen konden inladen. De chirurgijn van Z.Exc. verbond den vinger van fr. Harmen en bemestte die met goede koemist, tevens klagende, dat die hier te lande zoo goed niet was als in Europa ${ }^{\mathbf{1}}$ ). De reizigers besloten nu den tocht naar de Marowijne over zee uit te stellen en huis

$\left.{ }^{1}\right)$ „Koeyemis.... insonderheyt somers als de beesten in de wey gaen, versacht en verteert, verlicht pijn ende brant". Zie M. A.van Andel, Volksgeneeskunst in Nederland 1909, blz. 383. Voor zwerende vingers aldaar, blz. 387. 
toe te gaan. Dien middag at onze auteur weder bij neef Clefson, die thans thuis was, met schipper Booms, Sander Vos, den Engelschen kapitein, den heer Bresser met nog een planter, die „pieux soowel als schipper Booms sijnde ons daarom niet min vijandigh was." Omdat zij labadisten waren? Hij sprak ook nog een mons. Wijnbergen ,daer ick geen quaet contentement in hadde nopende onze waerheden", maar de kommies Cyprianus bleef voor en na de wereld aenhangen. Nadat de Heer hem genadig had bewaard voor verpletterd te worden onder een oxhoofd met legumes, dat van boven naar het strand d. i. den rivierkant werd gerold, ging het gezelschap weder scheep en een sijgen wints (een zuchtje winds) bracht hen tot aan den mond der Para.

Zondag 9 Juni roeiden zij toen om 6 uur de Para in en voorbij het fort, dat daar tegen deIndianen gebouwd was ${ }^{1}$ ). Maar de zieke hand van fr. Harmen werd erger, niettegenstaande zij de koemist telkens ververschten, en dus besloten zij niet verder te gaan. Maandag roeiden zij met de kano toch nog een goed stuk de kreek in tot aan de groote bocht, waar eertijds een kapitein Thorn gewoond had. Het was daar goede kleiïge grond, soms wat zandig. De plantages, waarvan de bewoners door de Indianen vermoord waren of die zij uit vrees verlaten hadden „verstrekten ons tot droevige monumenten van hun barbarische woede". Dan gingen zij terug naar de bark, kwamen om 4 uur weer voorbij het fort en voorts met den vloed een goed eind de Suriname op. Dinsdag 11 Juni met den wind achter bereikten zij weder Zandpunt, waar het Engelsche schip, van Boston gekomen, met provisie voor den heer Nassy lag ${ }^{2}$ ). Daarnaast lag ,het Engelsch scheepie daer wij mede van ijsle de Brava gekomen sijn" $\left.^{3}\right)$. Weder voorbij Ds. Basiliers, bij de joodsche synagoge ten anker, 's avonds met een „luchie van achteren”

1) Door Aerssens. Het was niet meer dan een versterkt steenen huis.

2) Nu misschien Jacob Nassy, die daar zijne plantage had, no. 32 van onze kaart.

s) Het eiland Brava in den archipel der Kaap Verdische eilanden. Doch welke reis was dat, tusschen de eerste en de tweede uitzending in ? 
tot den Mawelberg, die met recht zoo genoemd wordt, niet omdat er veel mawel in zit, maar omdat er altijd wat te marrelen, te sukkelen valt. Aldus onze schrijver met eene zeker toenmaals gangbare volksetymologie ${ }^{1}$ ). En zoo is dan de laatste dag aangebroken, Woensdag 12 Juni. Zij kwamen toen tot wat beneden Pieter Jaspers plantage, middagmaalden en daarna gingen fr. Robijn, Harmen en onze schrijver met een neger en kleinen Pito in de kano en waren om 5 uur thuis. Nauwelijks hadden zij voet aan land gezet of zij vernamen, dat de Heere Zijn huis wat bijzonderlijk bezocht had, hebbende Hij in zijne oneindige barmhartigheid fr. Jan Swanepoel tot zich genomen en bezocht met zeer zware pijnen en ziekten fr. Pieter, fr. Huybrecht ${ }^{2}$ ) met mas. Ester, fr. Hanske met mas. Swem (die wij kennen), fr. Sikke en Doeke zoowel als mas. Grietie Alberts. Meest al de kinderen hadden „quade viezige loopende oogen" en kleine Hendrik had het koud vuur in zijn voet gehad. Er was niemand vrij. „Wij daerentegen, die de meesten niet wel gestelt uijtgegaen waren, bevonden ons seer gesterkt en gesondt, uytgenomen fr. Herman aen zijn handt 't quaet hebbende. Gode alleen sij lof en danck in eeuwigheid."

De belangrijkheid van het ons in dit journaal gebodene springt in het oog. Het toont ons enkele labadisten in actie, moedig en schrander. Ook iets van hun geestelijk leven. Een ander beeld dan Dittelbach ons teekende. Toch niet geheel. Warit de ziekten, welke de emigranten teisterden vertoonen zich bij beide berichtgevers. En bij onze schaarste van gegevens moeten wij voor dit journaal dankbaar zijn, ook om de namen, die het noemt en de toestanden in de kolonie, die het, zij het kort, vermeldt. Het reisverhaal geeft op het einde nog eene beschrijving van de gronden langs de genoemde rivieren; die voor onze geschiedenis echter van geen belang is.

Van de verplaatsing der kolonie naar de Couremoutibo

$\left.{ }^{2}\right)$ Mawel of marvel, mergel, marga albicans, en mergelberg brengt op marrelen.

${ }^{2}$ ) Boven, blz. 15, de zalfbereider. 
is niets gekomen. In 1688, tijdens het soldatenoproer dat aan Aerssens het leven kostte, deed de bark der labadisten nog dienst in de Boven-Suriname ${ }^{\mathbf{1}}$ ). Of enkelen hunner zich misschien in het Noordoosten gevestigd hebben, weten wij niet. Alle gegevens omtrent den ondergang der nederzetting ontbreken. Van den verkoop der plantage in 1719 heb ik gesproken. Wij kunnen slechts hopen, dat nieuwe vondsten ons nog eens verder zullen brengen in onze kennis van deze merkwaardige secte gedurende de weinige ramspoedige jaren, die zij in het Surinaamsche binnenland doorworsteld hebben.

Juni 1926.

1) Aldus ds. Ort in Protest. blad 21 Aug. 1920 zonder bron. Th. Pistorius Korte en zakelijke beschrijvinge van de Colonie van Zuriname, 1763, geeft een uitvoerig verhaal van den moord op den gouverneur en het oproer, blz. 100 - 160. Er is daar sprake van twee regeeringsbarken en van de bark van schipper Maissonet, blz. 129, doch niet van die der labadisten. 